\title{
PENGARUH MODEL PEMBELAJARAN INKUIRI TERBIMBING TERHADAP HASIL BELAJAR SISWA PADA MATERI MACAM-MACAM GAYA
}

\author{
Liza Purnawati ${ }^{1}$, Aries Tika Damayani ${ }^{2}$, Kiswoyo ${ }^{3}$ \\ 1,2,3 Jurusan Pendidikan Guru Sekolah Dasar \\ Fakultas IImu Pendidikan Universitas PGRI Semarang \\ email : lizapurna78910@gmail.com
}

\begin{abstract}
ABSTRAK
Penelitian ini bertujuan untuk mengetahui pengaruh model pembelajaran inkuiri terbimbing terhadap hasil belajar pada materi macam-macam gaya. Jenis penelitian ini adalah eksperimen dengan menggunakan pendekatan kuantitatif. Dengan menggunakan desain penelitian Pre-Experimental Design dengan bentuk One Group Prettest-Posttest Design. Populasi penelitian ini adalah seluruh siswa kelas V SDN 1 Tanjungmojo Kendal tahun pelajaran 2018/2019. Sampel yang diambil adalah 30 siswa kelas V dengan menggunakan teknik Sampling Jenuh. Data dalam penelitian ini diperoleh melalui wawancara, tes, dan dokumentasi. Berdasarkan hasil analisis menunjukkan ada pengaruh pembelajaran menggunakan model inkuiri terbimbing terhadap hasil belajar. Berdasarkan rata-rata nilai Pretest hasil belajar IPA adalah 46,4 dan rata-rata nilai posttest hasil belajar adalah 82,133 dengan KKM mata pelajaran IPA 70. Hal ini terbukti pada analisis akhir dengan menggunakan uji $t$ diperoleh thitung $=$ 24,913 dan ttabel= 1,699. Karena thitung > ttabel maka HO ditolak dan Ha diterima. Jadi ada pengaruh model pembelajaran Inkuiri terbimbing terhadap hasil belajar siswa pada materi macam-macam gaya kelas V SDN 1 Tanjungmojo Kendal.
\end{abstract}

Kata kunci: Inkuiri terbimbing, hasil belajar, IPA

\begin{abstract}
This research aims to investigate the effect of guided inquiry learning models towards learning result in various styles of material. This type of research is quantitative research. By using a PreExperimental Design research design with the Prettest-Posttest Design One Group design. The population of this study was fifth grade students of SDN 1 Tanjungmojo Kendal academic year 2018/2019. The samples taken were 30 grade V students using Saturated Sampling techniques. The data in this study were obtained through interviews, tests, and documentation. Based on the results of the analysis, there is a learning model that uses guided inquiry on learning result. Based on the average value of science learning pretest results is 46.4 and the average value of the posttest score of learning result is 82.133 with KKM 70 science subjects. This is evident in the final analysis using the test obtained tcount $=24.913$ and $t$ table $=1.699$. Because $t$ count $>t$ table then $\mathrm{HO}$ is rejected and $\mathrm{Ha}$ is accepted. So there is an interaction of the Guided Inquiry learning model towards student learning result in the material for various styles of class $V$ at SDN 1 Tanjungmojo Kendal.
\end{abstract}

Keywords: guided inquiry, learning result, IPA 


\section{Pendahuluan}

Pendidikan merupakan aspek yang sangat penting bagi manusia karena melalui dunia pendidikan diharapkan dapat menghasilkan sumber daya manusia yang berkualitas untuk mendorong kemajuan suatu bangsa. Pendidikan dapat tercapai apabila siswa memperoleh hasil belajar yang baik. Keberhasilan seorang guru dalam pembelajaran adalah apabila siswa yang diampunya mendapatkan hasil belajar yang maksimal ditandai dengan nilai yang diperoleh. Sebagai guru yang profesional, guru harus melaksanakan tugas pokoknya sebagai seorang pendidik dan pengajar yang mempunyai tugas meliputi kemampuan dalam merencanakan, menjalankan, dan mengevaluasi hasil pembelajaran.

Pendidikan menurut Undang-undang No.20 Th 2003 yaitu usaha sadar dan terencana untuk mewujudkan suasana belajar dan proses pembelajaran agar peserta didik secara aktif mengembangkan potensi dirinya untuk memiliki kekuatan spiritual keagamaan, pengendalian diri, kepribadian, kecerdasan, akhlak mulia, serta ketrampilan yang diperlukan dirinya, masyarakat, bangsa, dan negara.

Menurut Aunurrahman (2009: 38) belajar seringkali diartikan sebagai "aktivitas untuk memperoleh pengetahuan dan berbagai kecakapan, keterampilan, dan sikap". Kemampuan orang untuk belajar menjadi ciri penting yang membedakan jenisnya dari jenis-jenis makhluk yang lain. Dalam konteks ini seseorang dikatakan belajar bilamana terjadi perubahan, dari sebelumnya tidak mengetahui sesuatu menjadi mengetahui.

Siswa adalah subjek yang terlibat dalam kegiatan belajar-mengajar di sekolah. Dalam kegiatan tersebut siswa mengalami tindak mengajar, dan merespon dengan tindak belajar. Pada umumnya semula siswa belum menyadari pentingnya belajar. Berkat informasi guru tentang sasaran belajar, maka siswa mengetahui apa arti bahan belajar baginya. Siswa mengalami suatu proses belajar. Dalam proses belajar tersebut, siswa menggunakan kemampuan mentalnya untuk mempelajari bahan ajar. Kemampuan-kemampuan pengetahuan (kognitif), sikap (afektif), keterampilan (psikomotorik) yang dibelajarkan dengan bahan belajar menjadi semakin rinci dan menguat. Adanya informasi tentang sasaran belajar, adanya penguatan-penguatan, adanya evaluasi dan keberhasilan belajar, menyebabkan siswa semakin sadar akan kemampuan dirinya. Hal ini akan memperkuat keinginan untuk semakin mandiri, jadi tujuan belajar penting bagi guru dan siswa sendiri.

Menurut Mujiono (dalam Sundayana, 2015: 25) "dalam proses belajar mengajar ada empat kompenen penting yang berpengaruh bagi keberhasilan belajar siswa, yaitu bahan belajar, suasana belajar, media belajar dan sumber belajar, serta guru sebagai subjek pembelajaran. Kompenen-kompenen tersebut sangat penting dalam proses belajar, sehingga melemahnya satu atau lebih komponen dapat menghambat tercapainya tujuan belajar yang optimal.

Menurut Hosnan (2014: 337) Model adalah prosedur yang sistematis tentang pola belajar untuk mencapai tujuan belajar serta sebagai pedoman bagi pengajar dalam merencanakan dan melaksanakan aktifitas pembelajaran. Model pembelajaran adalah kerangka konseptual/operasional, yang melukiskan prosedur yang sistematis dalam mengorganisasikan pengalaman belajar untuk mencapai tujuan belajar tertentu dan berfungsi sebagai pedoman bagi para pengajar dalam merencanakan, dan melaksanakan aktifitas pembelajaran guna mencapai hasil belajar siswa di sekolah yang maksimal dan memadai, diperlukan kreatifitas guru dalam menjalankan proses pembelajaran.

Kemampuan guru dalam memahami dan melaksanakan model pembelajaran tersebut sangat berpengaruh terhadap hasil yang dicapai. Ketidaktepatan menggunakan suatu model pembelajaran dapat menimbulkan kebosanan, kurangnya pemahaman siswa dan pembelajaran yang monoton sehingga mengakibatkan sikap yang acuh terhadap pelajaran IPA. Masalah ini seringkali menghambat dalam proses pembelajaran.

IPA adalah suatu ilmu pengetahuan yang mempelajari tentang alam sekitar beserta isinya. Menurut Trianto (2010:136-137) "IPA adalah suatu kumpulan yang sistematik, penerapanya secara umum berbatas pada gejala-gejala alam, lahir dan berkembang melalui 
metode ilmiah seperti observasi dan eksperimen serta menuntut sikap ilmiah seperti rasa ingin tahu, terbuka, jujur, dan sebagainya".

Berdasarkan hasil wawancara awal pada guru kelas V SDN 01 Tanjungmojo Kendal. Wawancara dilakukan dengan Ibu Siti Ma'rifah pada mata pelajaran IPA materi macam-macam gaya dan pengaruhnya siswa kurang menguasai, yang terlihat hanya $40 \%$ atau 12 siswa yang tuntas dari 30 siswa, dan dari kenyataan bahwa nilai ulangan harian pada mata pelajaran IPA sebesar $60 \%$ atau 18 siswa yang berada dibawah nilai Kriteria Ketuntasan Minimal (KKM). Nilai KKM pada mata pelajaran IPA yaitu 70 .

Tabel 1. Rekap Nilai Ulangan Harian Th.2017/2018

\begin{tabular}{ccc}
\hline No. & Keterangan Nilai & Jumlah Siswa \\
1 & $<70$ & 18 \\
2 & $70-85$ & 10 \\
3 & $86-100$ & 2 \\
\hline
\end{tabular}

Hal tersebut dikarenakan rendahnya penguasaan materi yang besar kemungkinan guru kurang tepat dalam memilih model pembelajaraan yang mengakibatkan siswa menjadi pasif dalam proses pembelajaran. Pembelajaran tersebut sehari-hari guru sudah menjelaskan secara lisan, ditulis di papan tulis, memberi contoh, serta memberikan soal-soal latihan tentang macam-macam gaya dan pengaruhnya, dan juga siswa sudah diberi kesempatan untuk bertanya ketika guru mengajar. Namun hanya sedikit siswa yang aktif dalam kegiatan tanya jawab tersebut. Untuk mengatasi masalah tersebut, solusi untuk meningkatkan kemampuan hasil belajar siswa dengan menggunakan model pembelajaran inkuiri terbimbing.

Pembelajaran inkuiri merupakan pembelajaran yang banyak dianjurkan, karena strategi ini memiliki beberapa keunggulan, salah satunya adalah pembelajaran inkuiri menekankan kepada pengembangan aspek kognitif, afektif, dan psikomotor secara seimbang, sehingga pembelajaran inkuiri ini dianggap lebih bermakna (Hosnan, 2014: 344). Pembelajaran inkuiri menekankan kepada proses mencari dan menemukan. Materi pelajaran tidak diberikan secara langsung. peran peserta didik dalam strategi ini adalah mencari dan menemukan sendiri materi pelajaran, sedangkan pendidik berperan sebagai fasilitator dan pembimbing peserta didik untuk belajar. Proses pembelajaran yang terjadi berpusat pada siswa sehingga pembelajaran ini lebih memotivasi siswa untuk aktif menyelesaikan tugas belajar dan diharapkan hasil belajar siswa meningkat. Maka dari itu penulis mengambil judul "Pengaruh Model Pembelajaran Inkuiri Terbimbing Terhadap Hasil Belajar Siswa Pada Materi Macam-Macam Gaya Kelas V SDN 1 Tanjungmojo"

Penelitian ini dikuatkan oleh penelitian sebelumna yang dilakukan oleh Iswatun (2017) yang menyatakan bahwa penerapan model pembelajaran inkuiri terbimbing dapat meningkatkan KPS dan hasil belajar kognitif siswa serta memberikan pengaruh positif antara KPS terhadap hasil belajar kognitif siswa. Septi Munatri (2016) yang menyatakan bahwa hasil belajar siswa materi sifat koligatif larutan dapat ditingkatkan dengan pembelajaran inkuiri terbimbing. Hani Nur'Azizah (2016) juga menyatakan bahwa model pembelajaran inkuiri terbimbing dapat meningkatkan kemampuan berpikir kritis siswa pada materi energi bunyi secara signifikan. Hal senada juga diungkapkan oleh Irham Falahudin (2016) menyatakan model pembelajaran inkuiri terbimbing pada materi pengelolaan lingkungan berpengaruh terhadap kemampuan berpikir kritis siswa di SMP Negeri 2 Tanjung Lago, Kabupaten Banyuasin.

Berdasarkan latar belakang masalah yang telah dikemukakan diatas, dapat mengidentifikasi masalah sebagai berikut: 1) Kurangnya penggunakan model pembelajaran yang kreatif sehingga menimbulkan kebosanan, siswa tidak aktif, dan monoton untuk siswa, 2) Rendahnya penguasaan materi, kemungkinan dikarenakan siswa kurang dalam pemahaman materi, 3) Siswa bersikap acuh terhadap pelajaran, sehingga kurang dalam memahami materi 
macam-macam gaya dan pengaruhnya, 4) Hasil belajar siswa masih rendah, hanya $40 \%$ siswa yang tuntas.

Berdasarkan latar belakang dan identifikasi masalah yang ada, maka peneliti melakukan pembatasan masalah agar permasalahan tidak meluas dan hasil yang diharapkan. Masalah dibatasi pada penggunaan model inkuiri terbimbing dan hasil belajar kognitif, pada mata pelajaran IPA materi macam-macam gaya dan pengaruhnya. Penelitian ini dilaksanakan di kelas V semester 1 tahun 2018/2019. Penelitian dilaksanakan di SDN 1 Tanjungmojo Kendal.

KD: 5.1 mendeskripsikan hubungan antara gaya, gerak, dan energi melalui percobaa (gaya gravitasi, gaya gesek, gaya magnet)

Berdasarkan identifikasi masalah dan pembatasan masalah diatas, maka perumusan masalah ini adalah apakah ada pengaruh model pembelajaran inkuiri terbimbing terhadap hasil belajar siswa pada materi macam-macam gaya kelas V SDN 1 Tanjungmojo Kendal? Berdasarkan rumusan masalah diatas, maka tujuan penelitian ini adalah untuk mengetahui pengaruh model pembelajaran inkuiri terbimbing terhadap hasil belajar siswa pada materi macam-macam gaya kelas V SDN 1 Tanjungmojo Kendal.

\section{Metode}

Pada penelitian ini penulis menggunakan metode Experimen. Menurut Sugiyono (2010: 107) "Metode eksperimen dapat diartikan sebagai metode penelitian yang digunakan untuk mencari pengaruh perlakuan tertentu terhadap yang lain dalam kondisi yang terkendalikan". Menurut Arikunto, (2010: 9) "eksperimen adalah suatu cara untuk mencari hubungan sebab akibat (hubungan kausal) antara dua faktor yang sengaja ditimbulkan oleh peneliti dengan mengeliminasi atau mengurangi atau menyisihkan faktor-faktor lain yang mengganggu". Bentuk desain experimen yang digunakan yaitu Pre-Experimental Design. Bentuk Pre Experimen Design yang digunakan adalah One Group Prettest-Posttest Design. Dengan demikian hasil perlakuan dapat dketahui lebih akurat, karena membandingkan dengan keadaan sebelum diberi perlakuan.

Populasi penelitian ini adalah seluruh siswa kelas V SDN 1 Tanjungmojo Kendal tahun pelajaran 2018/2019. Sampel yang diambil adalah 30 siswa kelas V dengan menggunakan teknik Sampling Jenuh.

Teknik pengumpulan data dalam penelitian ini yaitu wawancara, tes, dan dokumentasi. Untuk mengukur hasil belajar menggunakan model inkuiri terbimbing yaitu menggunakan tes. Pada penelitian ini instrumen tes berupa soal pilihan ganda. Soal tes yang digunakan untuk mengetahui seberapa besar pengaruhnya terhadap hasil belajar siswa. Tes berupa pretest dan posttest.

\section{Hasil Dan Pembahasan}

Data hasil penelitian diperoleh dari nilai pretest dan posttest hasil belajar siswa. Nilai pretest dan posttest dinyatakan tuntas jika memenuhi nilai KKM. Adapun Kriteria Ketuntasan Maksimal (KKM) mata pelajaran IPA SDN 1 Tanjungmojo yaitu 70. Perhitungan nilai pretest dan nilai posttest setelah diberikan perlakuan hasilnya berbeda. Berikut tabel nilai pretest dan posttest siswa kelas V SD Negeri 01 Tanjungmojo Kendal.

Data hasil belajar nilai pretest dan posttest siswa kelas V SD Negeri Tanjungmojo 1 Kendal tahun ajaran 2018/2019 dapat dilihat pada tabel 4.1:

Tabel 1. Data Hasil pretest dan posttest

\begin{tabular}{lll}
\hline Keterangan & Pretest & Posttest \\
\hline Nilai tertinggi & 76 & 96 \\
Nilai terendah & 20 & 60 \\
Rata-rata & 46,4 & 82,133 \\
\hline
\end{tabular}




\begin{tabular}{lll}
\hline Siswa tuntas & 3 & 28 \\
Siswa tidak tuntas & 27 & 2 \\
\hline
\end{tabular}

Berdasarkan tabel tersebut menunjukkan bahwa terdapat peningkatan antara nilai pretest yang sebelum diberikan perlakuan dengan nilai posttest yang sudah diberikan perlakuan dengan menggunakan model Inkuiri Terbimbing.

Hasil nilai pada penelitian ini yang dijadikan sebagai data akhir penelitian yaitu nilai posttest. Data yang diperoleh kemudian digunakan uji normalitas dan uji t untuk menguji hipotesis penelitian ada atau tidak ada perbedaan hasil belajar yang sigifikan antara pretest dan posttest.

Data nilai psikomotorik diperleh dari observasi selama proses pembelajaran menggunakan model Inkuiri Terbimbing di SDN 1 Tanjungmojo. Berikut rekapitulasi nilai ratrata psikomotorik siswa:

Tabel 2. Rekapitulsi Nilai Rata-rata Psikomotorik

\begin{tabular}{llccccc}
\hline \multirow{2}{*}{ No } & \multirow{2}{*}{ Aspek } & \multicolumn{5}{c}{ Nilai } \\
\cline { 2 - 5 } & & P1 & P2 & P3 & P4 & \\
\hline 1 & Mengemukakan Masalah & 88 & 88,5 & 82,5 & 89,5 & 87,1 \\
2 & Membuat Hipotesis & 90 & 90 & 88 & 91,5 & 89,9 \\
3 & Merancang Percobaan & 89 & 91 & 89 & 89,5 & 89,6 \\
4 & Melakukan Percobaan & 84 & 84 & 82 & 84 & 83,5 \\
5 & Pengumpulan dan Analisis Data & 83 & 85 & 83 & 84,5 & 83,9 \\
6 & Membuat Hipotesis & 79 & 79 & 79 & 81 & 79,5 \\
\hline
\end{tabular}

Analisis data awal dilakukan untuk mengkaji apakah sampel berasal dari data berdistribusi normal atau tidak. Uji normalitas data awal pada penelitian ini menggunakan data pretest. Pengujian normalitas menggunakan uji liliefors pada taraf signifikan sebesar $5 \%$. Dari hasil perhitungan menggunakan uji liliefors dapat dilihat pada tabel berikut:

Tabel 2. Hasil Uji Normalitas Data Awal (Pretest)

\begin{tabular}{ll}
\hline Data & Pretest \\
\hline $\mathrm{L}_{0}$ & 0,1266 \\
$\mathrm{~L}_{\text {tabel }}$ & 0,161 \\
Kriteria & Berdistribusi Normal \\
\hline
\end{tabular}

Berdasarkan tabel tersebut dapat dijelaskan bahwa diperoleh nilai $L_{0}=0,1266$ dengan taraf signifikan $5 \% n=30$ maka diperoleh $L_{\text {tabel }}=0,161$. Karena $L_{0}<L_{\text {tabel }}$ maka artinya data berdistribusi normal. Jadi data nilai pretest menunjukkan bahwa sampel berasal dari populasi berdistribusi normal. Data akhir diperoleh dari nilai posttest siswa kelas V SDN 1 Tanjungmojo Kendal. Data berasal dari soal posttest yang terdiri dari 30 butir soal pilihan ganda. Untuk mengetahui data ini perlu dilakukan uji normalitas data. Data hasil perhitungan menggunakan uji liliefors dapat dilihat pada tabel berikut:

Tabel 3. Hasil Uji Normalitas Data Nilai Posttest

\begin{tabular}{ll}
\hline Data & Posttest \\
\hline$L_{0}$ & 0,1027 \\
$L_{\text {tabel }}$ & 0,161 \\
Kriteria & Berdistribusi Normal \\
\hline
\end{tabular}


Berdasarkan hasil pengujian normalitas data posttest diperoleh nilai $\mathrm{L}_{0}=0,1027$ dengan taraf signifikan $5 \% n=30$ maka diperoleh $L_{\text {tabel }}=0,161$. Karena $L_{0}<L_{\text {tabel }}$ maka artinya data berdistribusi normal. Jadi data nilai posttest menunjukkan bahwa sampel berasal dari populasi berdistribusi normal.

Setelah itu dilakukan uji hipotesis. Pengujian hipotesis menggunakan uji t satu sampel. Uji t satu sampel merupakan salah satu uji parametrik.

Tabel 4. Hasil Perhitungan Uji t

\begin{tabular}{lll}
\hline Uji t & Pretest & Posttest \\
\hline Jumlah & 1392 & 2464 \\
Rata-rata & 46,4 & 82,133 \\
Md & 35,733 & \\
$\sum_{N} X^{2} d$ & 1072 & \\
$N(N-1)$ & & \\
$t_{\text {nitung }}$ & 1789,867 & \\
$t_{\text {tabel }}$ & & \\
Keterangan & 30 & \\
\hline
\end{tabular}

Berdasarkan Tabel 4 diperoleh harga $t_{\text {hitung }}=24,913$. Selanjutnya harga $t_{\text {hitung }}$ tersebut dibandingkan dengan $t_{\text {tabel }}=1,699$ dengan $\mathrm{db}=30-1$ pada taraf signifikan $5 \%$, sehingga diperoleh harga $t_{\text {hitung }}>t_{\text {tabel }}$ yaitu 24,913 $>1,699$. Dengan demikian Ho ditolak dan Ha diterima. Dapat disimpulkan bahwa ada pengaruh model Inkuiri Terbimbing terhadap hasil belajar IPA materi macam-macam gaya kelas V SDN 1 Tanjungmojo Kendal.

Penelitian ini berjudul "Pengaruh Model Pembelajaran Inkuiri Terbimbing Terhadap Hasil Belajar Siswa Pada Materi Perubahan Sifat Benda Kelas V SDN 1 Tanjungmojo Kendal". Tujuan penelitian ini adalah untuk mendeskripsikan pengaruh model Inkuiri Terbimbing terhadap hasil belajar pada materi macam-macam gaya. Penelitian ini dilaksanakan pada semester ganjil tahun ajaran 2018/2019 pada kelas $V$ dengan jumlah 30 siswa. Diawali dengan melakukan wawancara kepada guru kelas V pada 28 Mei 2018 kemudian dilakukan penelitian pada bulan November 2018. Penelitian ini termasuk penelitian kuantitatif. Desain yang digunakan adalah One-Group Pretest-Posttest Design.

Sebelum penelitian dilaksanakan peneliti mempersiapkan RPP yang dilaksanakan dalam empat kali pertemuan. Masing-masing rencana pelaksanan pembelajaran menggunakan model pembelajaran Inkuiri Terbimbing sesuai dengan tahap-tahap pembelajaran model pembelajaran Inkuiri Terbimbing. Pembelajaran model Inkuiri Terbimbing dilakukan dengan membentuk 6 kelompok dengan masing-masing kelompok beranggotakan 5 siswa. Setiap kelompok melakukan percobaan sesuai dengan Lembar Kerja Siswa yang telah dibuat sesuai dengan langkah pembelajaran yang telah ditentukan. Sebelum melakukan pembelajaran dengan menggunakan model Inkuiri Terbimbing terlebih dahulu membagikan soal pretest kemudian diakhir pembelajaran diberikan soal posttest untuk mengetahui hasil setelah diberi perlakuan.

Berdasarkan penelitian yang sudah dilakukan hasil tes pretest menunjukkan bahwa dari 30 siswa hanya 3 anak yang mencapai nilai KKM. Nilai KKM pada mata pelajaran IPA yaitu 70 . Nilai terendah 20, nilai tertinggi 76 Dengan rata-rata nilai pretest 46,4. Sedangkan hasil posttest menunjukkan bahwa dari 30 siswa hanya 2 siswa yang tidak tuntas. Nilai terendah 60 , nilai tertinggi 96 dengan rata-rata nilai 82,133 . Hal ini menunjukkan adanya perbedaan antara hasil belajar sebelum menggunakan model Inkuiri Terbimbing dan hasil belajar setelah menggunakan dengan model inkuiri terbimbing. Sedangkan untuk hasil psikomotorik siswa, 
dalam pembelajaran dinilai dari aspek model Inkuiri Terbimbing yang masing-masing ditentukan indikator tiap aspek. Indikator penilaian dari aspek mengemukakan masalah yaitu siswa mampu memahami masalah yang ada di LKS, siswa mampu menemukakan masalah dengan benar, indikator aspek membuat hipotesis yaitu siswa mampu menentukan hipotesis yang relevan dengan permasalahan yang ada di LKS, indikator aspek merancang percobaan yaitu siswa mampu menyiapkan alat dan bahan dengan lengkap, siswa mampu menentukan langkah-langkah untuk percobaan, indikator aspek melakukan percobaan yaitu siswa mampu melakukan percobaan sesuai langkah kerja dengan runtut, indikator aspek pengumpulan data dan analisis data yaitu siswa mampu mengumpulkan dan menganalisis data dari percobaan yang telah dilakukan, siswa mampu menyampaikan hasil pengumpulan data dengan baik dan benar, indikator aspek membuat kesimpulan yaitu siswa mampu membuat kesimpulan dengan baik dan benar. Masing-masing indikator skor maksimal 4 dengan kriteria baik sekali. Nilai psikomotorik dilakukan saat proses pembelajaran menggunakan model Inkuiri Terbimbing, diperoleh rata-rata nilai psikomotorik tiap aspek.

Sesuai dengan penelitian yang saya lakukan dengan menggunakan model Inkuiri Terbimbing siswa mampu mengemukakan masalah sehingga dari permasalahan tersebut muncul dugaan atau jawaban sementara yang belum dibuktikan kebenarannya, untuk membuktikkan dugaan sementara siswa merancang percobaan kemudian melakukan percobaan sesuai dengan langkah kerja, dari hasil percobaan siswa mengumpulkan jawabanjawaban untuk membuktikkan dugaan sementara.

Analisis data pada penelitian terdiri dari data awal dan data akhir. Berdasarkan hasil analisis data awal ini diketahui bahwa data berdistribusi normal dengan nilai $L_{0}=0,1266$ dengan taraf signifikan $5 \% n=30$ maka diperoleh $L_{\text {tabel }}=0,161$. Sedangkan hasil analisis data akhir yang telah dilakukan dengan uji normalitas menunjukkan bahwa sampel berasal dari populasi yang berdistribusi normal dengan $L_{0}=0,1027$ dengan taraf signifikan $5 \% n=30$ maka diperoleh $\mathrm{L}_{\text {tabel }}=0,161$.

Hasil hipotesis menggunakan uji t membuktikan bahwa terdapat pengaruh model pembelajaran Inkuiri Terbimbing terhadap hasil belajar IPA kelas V pada materi macammacam gaya SDN 1 Tanjungmojo Kendal. Berdasarkan perhitungan uji $t$ dari hasil belajar diperoleh $t_{\text {hitung }}=24,913$ dan $t_{\text {tabel }}=1,699$. Karena $t_{\text {hitung }}>t_{\text {tabel }}$ maka $\mathrm{H}_{0}$ ditolak dan $\mathrm{H}_{\mathrm{a}}$ diterima.

Menurut teori Brunner (dalam Susanto, 2013: 98) pembelajaran penemuan, adalah suatu model pengajaran yang menekankan pentingnya pemahaman tentang struktur materi dari suatu ilmu yang dipelajari perlunya belajar secara aktif sebagai dasar dari pemahaman sebenarnya, dan nilai dari berpikir secara induktif dalam belajar.

Menurut Brunner belajar akan lebih bermakna bagi siswa jika mereka memusatkan perhatian untuk memahami struktur materi yang dipelajarinya. Untuk mempelajari struktur informasi, siswa harus aktif, dimana mereka harus mengidentifikasi sendiri prinsip-prinsip kunci daripada hanya sekedar menerima penjelasan dari guru. Oleh karena itu guru harus memecahkan masalah yang mendorong siswa untuk melakukan kegiatan penemuan. Sesuai pendapat Brunner maka saya mengaplikasikan kedalam penelitian saya menggunakan model inkuiri terbimbing. Dalam penelitian yang saya lakukan siswa mampu mengemukakan masalah sehingga dari permasalahan tersebut muncul dugaan sementara yang belum dibuktikan kebenarannya, untuk membuktikkan dugaan sementara siswa merancang percobaan kemudian melakukan percobaan sesuai dengan langkah kerja, dari hasil percobaan siswa mengumpulkan jawaban-jawaban untuk membuktikkan dugaan sementara. Sehingga siswa mampu memecahkan masalah.

Sesuai dengan keunggulan model Inkuiri Terbimbing dimana disebutkan (Hosnan, 2014: 344) pembelajaran inkuiri menekankan kepada pengembangan aspek kognitif, afektif dan psikomotor secara seimbang, sehingga pembelajaran ini dianggap lebih bermakna. Pembelajaran inkuiri dapat memberikan ruang kepada siswa untuk belajar sesuai dengan gaya belajar mereka. Dalam penelitian yang saya lakukan hanya menekankan pada penilaian kognitif serta psikomotoriknya, yang menekankan siswa belajar sesuai dengan pemikiranya sendiri untuk belajar penemuan. 
Seperti halnya teori diatas, berdasarkan penelitian yang relevan oleh I Made Artana, Nyoman Dantes, I Wayan Lasmawan, (2015) penelitian ini juga sangat mendukung adanya penggunaan model Inkuiri Terbimbing terhadap hasil belajar IPA. Hal tersebut dapat dibuktikan bahwa hasil belajar IPA siswa yang mengikuti pembelajaran dengan model pembelajaran inkuiri terbimbing lebih baik daripada hasil belajar IPA siswa yang mengikuti pembelajaran tanpa menggunakan model pembelajaran. Hal ini dibuktikan dari rata-rata skor hasil belajar IPA siswa yang mengikuti pembelajaran dengan model inkuiri terbimbing yaitu 79,50 sedangkan rata-rata skor hasil belajar IPA yang mengikuti pembelajaran dengan model pembelajaran konvensional yaitu 71,40. Sehingga secara keseluruhan, hasil belajar IPA dengan menggunakan model Inkuiri Terbimbing lebih tinggi daripada model pembelajaran yang konvensional.

Langkah-langkah dalam model pembelajaran inkuiri ( Eggen \& Kauchak dalam Trianto dalam Zuldafrial, 2012: 131) yaitu: (1) Mengemukakan masalah, (membimbing siswa mengidentifikasi masalah) dengan nilai rata-rata 87,1, (2) Membuat hipotesis, (memberikan kesempatan kepada siswa untuk curah pendapat dalam membentuk hipotesis) dengan ratarata 89,9, (3) Merancang percobaan, (memberikan kesempatan kepada siswa untuk menentukan langkah-langkah yang sesuai dengan hipotesis yang akan dilakukan, membimbing dan mengurutkan langkah-langkah percobaan) dengan rata-rata 89,6, (4) Melakukan percobaan, (membimbing siswa mendapatkan informasi melalui percobaan) dengan rata-rata 83,5 , (5) Mengumpulan data dan menganalisis data, (memberikan kesempatan kepada kelompok untuk menyampaikan hasil percobaan) dengan rata-rata 83,9, (6) Membuat kesimpulan dari hasil percobaan dengan rata-rata 79,5. Dengan tahap-tahap model pembelajaran Ikuiri Terbimbing yang telah dilakukan maka membuat siswa menjadi lebih aktif dan mempermudah pemahaman siswa dalam pembelajaran, sehingga hasil belajar siswa meningkat pada materi macam-macam gaya.

Berdasarkan paparan data yang diperoleh dari penelitian dapat disimpulkan bahwa terdapat pengaruh penggunaan model Inkuiri Terbimbing terhadap hasil belajar dibandingkan dengan menggunakan model pembelajaran konvensional. Hal tersebut dapat dilihat dari hasil belajar siswa yang meningkat dan suasana kelas anak lebih aktif serta membuat pembelajaran jadi menyenangkan.

\section{Simpulan dan Saran}

Berdasarkan hasil penelitian dan pembahasan, maka dapat disimpulkan bahwa ada peningkatan hasil belajar siswa dengan menggunakan model Inkuiri Terbimbing, dengan rincian hasil sebagai berikut:

Ada pengaruh hasil belajar siswa menggunakan model inkuiri terbimbing yang dibuktikan dengan peningkatan hasil belajar sebelum dan sesudah diberi perlakuan. Sebelum diberi perlakuan rata-rata hasil belajar siswa 46,4 sedangkan setelah diberi perlakuan rata-rata nilai hasil belajar siswa 82,133. Berdasarkan perhitungan uji $t$ dari hasil belajar diperoleh thitung $=$ 24,913 dan ttabel= 1,699. Karena thitung > ttabel maka $\mathrm{HO}$ ditolak dan $\mathrm{Ha}$ diterima. Berdasarkan data yang diperoleh dari penelitian dapat disimpulkan bahwa model Inkuiri Terbimbing berpengaruh terhadap hasil belajar siswa kelas $\mathrm{V}$ SDN 1 Tanjungmojo dibandingkan dengan menggunakan model pembelajaran konvensional

Berdasarkan simpulan diatas setelah melakukan penelitian ini, maka peneliti memberikan beberapa saran, yaitu: 1) Guru diharapkan menggunakan model pembelajaran yang tepat, seperti model pembelajaran Inkuiri Terbimbing yang bisa meningkatkan hasil belajar siswa, 2) Berdasarkan penelitian yang dilaksanakan, saat pembelajaran berlangsung guru harus selalu memantau dan memperhatikan keselamatan saat percobaan, 3) Guru diharapkan lebih memperhatikan kegiatan siswa agar tahu bagaimana siswa melakukan percobaan sesuai langkah-langkah model Inkuiri terbimbing yang digunakan, dengan harapan dapat 
meningkatkan keaktifan siswa melalui percobaan atau praktek yang dapat membantu siswa dalam pemahaman materi sehingga hasil belajar siswa meningkat.

\section{Daftar Rujukan}

Arikunto, Suharsimi. 2010. Prosedur Penelitian Suatu Pendekatan Praktik. Jakarta: Rineka Cipta.

Aunurrahman. 2009. Belajar dan Pembelajaran. Bandung: Alfabeta.

Hani Nur'Azizah, Asep Kurnia Jayadinata, Diah Gusrayani. 2016. Pengaruh Model Pembelajaran Inkuiri Terbimbing Terhadap Kemampuan Berpikir Kritis Siswa Pada Materi Energi Bunyi. Jurnal Pena IImiah UPI. Vol. 1, No. 1.

Hosnan.M. 2014. Pendekatan Saintifik dan Kontekstual dalam Pembelajaran abad 21. Bogor: Ghalia Indonesia.

Irham Falahudin, Indah Wigati, Ayu Pujiastuti. 2016. Pengaruh Model Pembelajaran Inkuiri Terbimbing Terhadap Kemampuan Berpikir Kritis Siswa Pada Pembelajaran Materi Pengelolaan Lingkungan Di Smp Negeri 2 Tanjung Lago, Kabupaten Banyuasin. Jurnal Bioilmi UIN. Vol. 2 No. 2.

Iswatun Iswatun, Mosik Mosik, Bambang Subali. 2017. Penerapan model pembelajaran inkuiri terbimbing untuk meningkatkan KPS dan hasil belajar siswa SMP kelas VIII. Jurnal Inovasi Pendidikan IPA UNY. 3 (2), 2017-151

Septi Munatri, Agus Suyatna, Dwi Yulianti. 2016. Penerapan Model Pembelajaran Inkuiri Terbimbing Untuk Meningkatkan Hasil Belajar. Jurnal Teknologi Informasi Komunikasi Pendidikan Unila. Vol 4, No 1.

Sugiyono. 2010. Metode Penelitian Pendidikan. Bandng: Alfabeta.

Sundayana, Rostina. 2015. Media dan Alat Peraga Dalam Pemelajaran Matematika. Bandung: Alfabeta.

Susanto, Ahmad. 2013. Teori Belajar Pembelajaran di Sekolah Dasar. Jakarta: Kencana.

Trianto. 2010. Model Pembelajaran Terpadu Konsep,Strategi, dan Implementasinya dalam Kurikulum Tingkat Satuan Pendidikan (KTSP). Jakarta: PT Bumi Aksara.

Undang-undang Nomor 20 Tahun 2003 Tentang Sistem Pendidikan Nasional.

Zuldafrial. 2012. Strategi Belajar Mengajar.Surakarta: Cakrawala Media.. 